\title{
Exraspinal Teratoma-A Rare Case Report
}

\author{
Neema Tiwari ${ }^{1 *}$, Nishi Tandon ${ }^{1}$, A.N Srivastava ${ }^{1}$ and Osman Musa ${ }^{2}$ \\ ${ }^{1}$ Department of Pathology, ERA's Lucknow Medical College, India \\ 2Department of Surgery, ERA's Lucknow Medical College, India
}

Submission: September 20, 2017; Published: October 23, 2017

*Corresponding author: Neema Tiwari, Eras Lucknow Medical College and hospital, Lucknow, India, Email: nehaneemat@yahoo.co.in

\begin{abstract}
Sacrococcygeal teratoma (SCT) is a well known tumor of the newborn with a male: female ratio of about 1: 3 has an excellent prognosis provided adequate surgical treatment is given to the patient. Teratoma is believed to arise from the totipotent somatic cells that originate from the primitive knot (Hensen's node) presenting usually attached to the coccyx. We present a case report of a 1 year female who presented with midline swelling in the saccrococcygeal region since birth. The baby was operated and specimen sent for histopathology, where a diagnosis of extra spinal teratoma was made. The patient was kept on one month follow-up after 15 day post operative period and is healthy.
\end{abstract}

\section{Introduction}

Sacrococcygeal teratoma (SCT) is a well known tumor of the newborn with a male: female ratio of about 1: 3 has an excellent prognosis provided adequate surgical treatment is given to the patient 1 . It has a reported incidence of approximately one in 35,000-40,000 live births [1-3]. Although generally a rare condition, it is said to be the most common tumor in the neonatal period. Historically, teratomas were attributed to demons, sexual misconduct and abnormal fertilization [4]. However scientifically there are many conflicting theories for its origin, the most commonly accepted theory being the presence of three germ cell layers giving rise to teratomas of various sizes and shapes $[4,5]$. Teratoma is believed to arise from the totipotent somatic cells that originate from the primitive knot (Hensen's node) presenting usually attached to the coccyx $[5,6]$. Here with we present a case report of a 1 year female who presented with midline swelling in the saccro-coccyxegeal region since birth. The baby was operated and specimen sent for histopathology, where a diagnosis of extra spinal teratoma was made. The patient was kept on one month follow-up after 15 day post operative period and is healthy.

\section{Case History}

A 1 year female presented with swelling in the lumbar region with difficulty in walking. Spinal MRI revealed a heterogeneously enhancing mass lesion in the saccrococcygeal region. All other routine investigations were within normal limits.

Gross findings: A globular soft tissue piece with attached skin measuring $6 \times 5 \times 3 \mathrm{cms}$ was received. The growth measured $4 \times 2 \mathrm{cms}$ while the skin ellipse measured $2 \times 3 \mathrm{cms}$. Outer surface of growth had mucosal rugosities while inner surface had fibrofatty tissue and cartilaginous areas. Specimen was fixed in $10 \%$ formalin after giving multiple incisions for the formalin to penetrate.

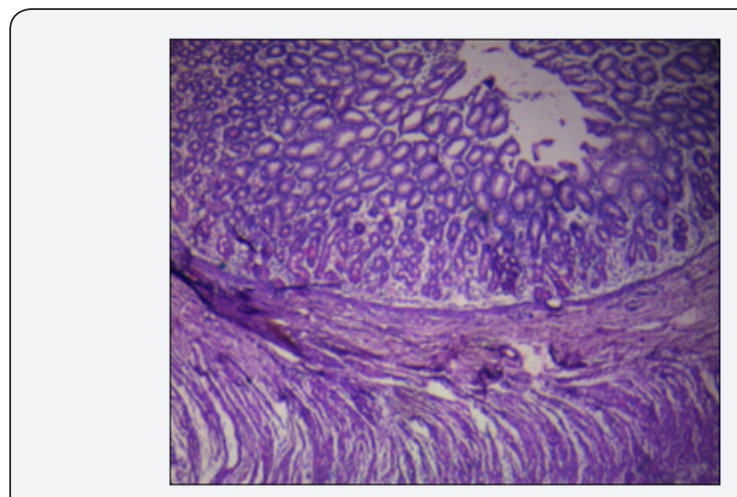

Figure 1: Showing mature intestinal mucosa.

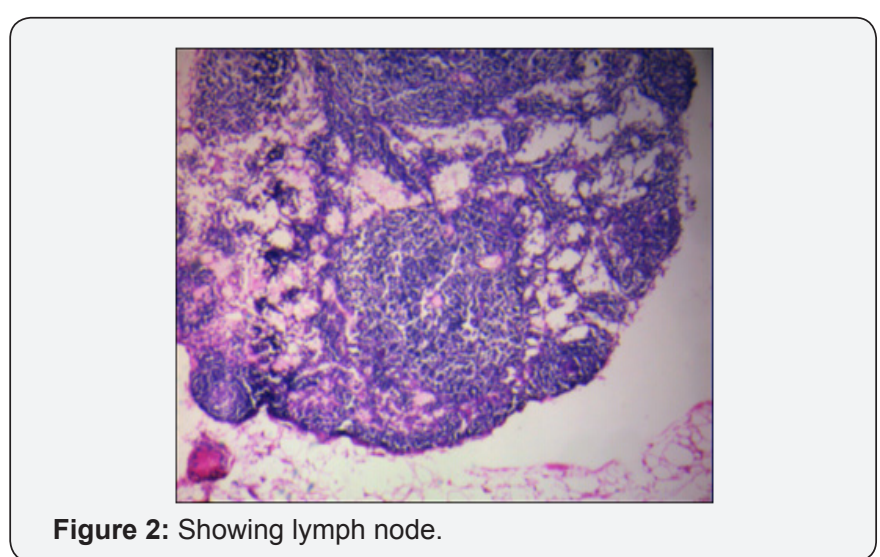




\section{Juniper Online Journal of Case Studies}
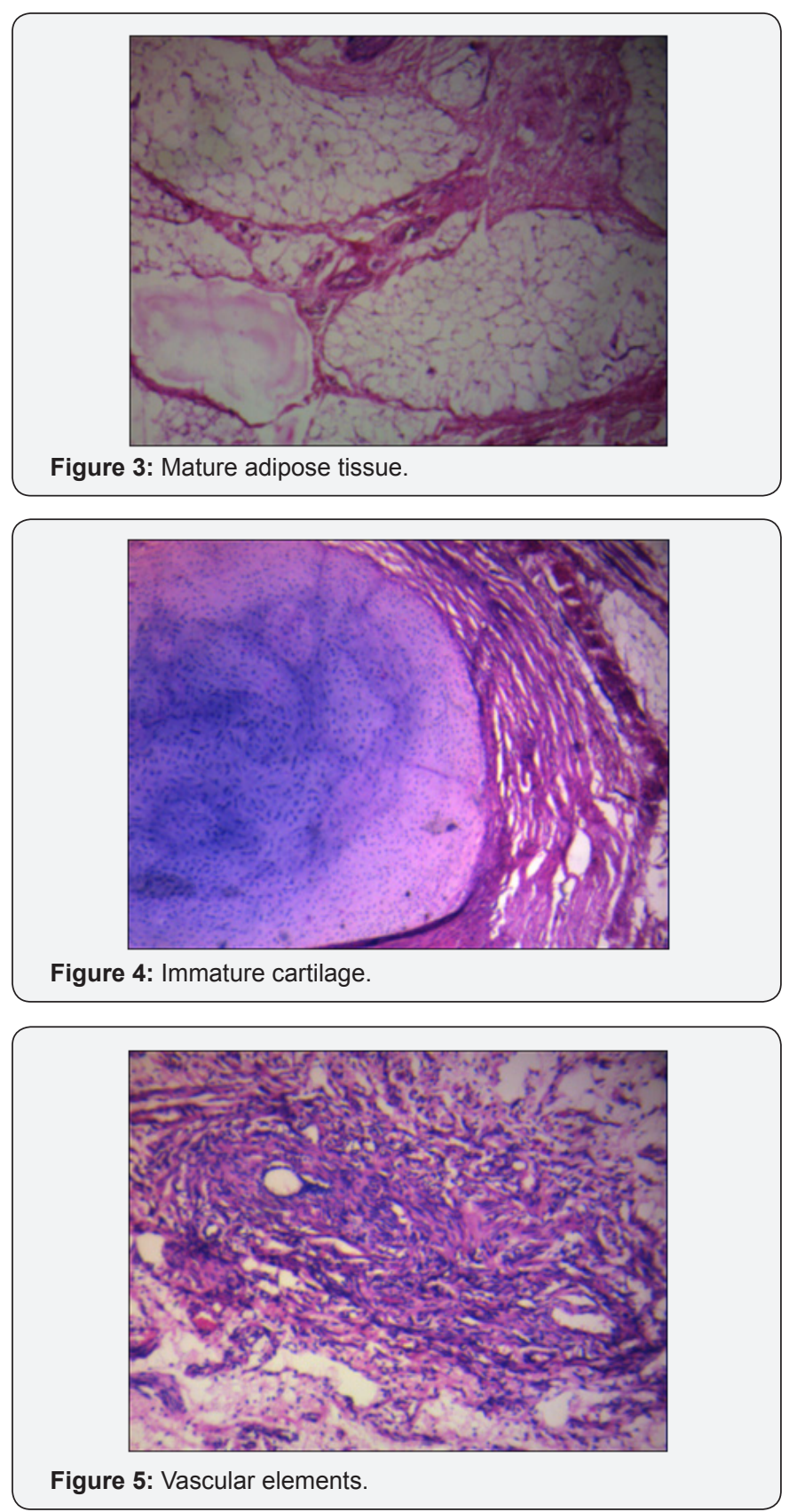

Microscopic examination: Section from tissue show stratified squamous epithelial lining. Underlying fibrocollagenous stroma show glands lined by mucin containing columnar cells. Section also showed smooth muscle fibres, adipocytes, gastrointestinal epithelium, nerve fibres, lymphoid tissue and cartilage and mild chronic inflammatory infiltrate was also seen. A diagnosis of extra spinal teratoma was made (Figure 1-5).

\section{Discussion}

Immature malignant sacrococcygeal teratoma (SCT) is a rare tumor occurring in the neonates with a female predilection. The most frequent site of tumor occurrence is the lumbar region and the child usually presents with a lumbar region growth. The most common theory accepted for its development is that it is a benign tumor that has been derived from the three germinal layers in the sacrococcygeal region [3]. The incidence of this tumor type is one in 35,000 to 40,000 live births.The most common diagnostic modality available for its diagnosis is the prenatal ultrasound and magnetic resonance imaging (MRI). Due to lack of study data in the field of Sacrococcygeal and cervical teratomas, they are being considered an interesting field for research [7].

Human tails and pseudotails are rare sacrococcygeal lesions that are associated with a wide variety of anomalies and syndromes. These tails and pseudotails occur in common conjunction with Anorectal malformations. These malformations are relatively uncommon congenital defects that often occur in with syndromes or other congenital abnormalities [8]. The anomalies associated with both disorders determine the timing and approach to surgical correction. Presence of both imperforate anus and a pseudo tail in the absence of a syndrome or other associated anomalies is an unusual phenomenon necessitating the need of a thorough preoperative evaluation. A true tail is defined as the remnant of the embryonic tail, which usually regresses during the seventh and eighth weeks of gestation. A pseudo tail is a protrusion from the lumbosacrococcygeal area that may be composed of normal or abnormal tissues but is not derived from the embryologic tail [7].

In contrast to the newborn with SCT, the fetus in utero with SCT remains at high risk of perinatal complications and death [9]. Fetuses with SCT detected antenatally have three times mortality rate compared with postnatally diagnosed neonates [10]. The cause of in utero fetal death can be maternal obstetric complications of tumor rupture, preterm labor, or dystocia [9]. The typical presentation of SCT as a skin-covered lumbosacral masses in the newborns leads to an array of possible diagnoses, ranging from benign hamartomas to aggressive malignancies and meningoceles [9].

A neonate with sacrococcygeal teratoma (SCT) has an excellent prognosis depending on the timing of diagnosis, the ease of surgical resection and malignant potential of the tumor [10].

\section{Conclusion}

Anorectal malformations and skin-covered midline growths present as a challenging diagnostic and therapeutic entities because of the extensive differential diagnoses ranging from benign hamartomas to aggressive malignancies and meningocoele and the array of associated anomalies. Hence extensive discussion and research is needed to improve the neonatal morbidity and mortality due to extra spinal teratomas.

\section{References}

1. Amirjamshidi A, Abbassioun K, Bidabadi MS (2006) Skin-covered midline spinal anomalies: a report of four rare cases with a discussion on their genesis and milestones in surgical management. Child's Nervous System 22(5): 460-465. 
2. Lu FL, Wang PJ, Teng RJ, Yau KI (1998) The human tail. Pediatr Neurol 19(3): 230-233.

3. Dusmet M, Fete F, Crusi A, Cox JN (1988) VATER association: report of a case with three unreported malformations. J Med Genet 25(1): 57-60.

4. Kahler RJ, Merry GS (1998) Spinal dysraphism and the Currarino triad. J Clin Neurosci 5(3): 339-342.

5. Dao AH, Netsky MG (1984) Human tails and pseudotails. Hum Pathol 15(5): 449-453.

6. Dubrow TJ, Wackym PA, Lesavoy MA (1988) Detailing the human tail. Ann Plast Surg 20(4): 340-344.
7. Guven MA, Uzel M, Ceylaner S, Coskun A, Ceylaner G, et al. (2008) A prenatally diagnosed case of sirenomelia with polydactyly and vestigial tail. Genet Couns 19(4): 419-424.

8. Parikh TB, Nanavati RN, Udani RH (2005) Sirenomelia apus with vestigial tail. Indian J Pediatr 72(4): 367.

9. Donovan DJ, Pedersen RC (2005) Human tail with noncontiguous intraspinal lipoma and spinal cord tethering: case report and embryologic discussion. Pediatr Neurosurg 41(1): 35-40.

10. Noack F, Reusche E, Gembruch U (2003) Prenatal diagnosis of 'true tail' withcartilage content? Fetal Diagn Ther 18(4): 226-229.

\section{Your next submission with Juniper Publishers will reach you the below assets}

- Quality Editorial service

- Swift Peer Review

- Reprints availability

- E-prints Service

- Manuscript Podcast for convenient understanding

- Global attainment for your research

- Manuscript accessibility in different formats ( Pdf, E-pub, Full Text, Audio)

- Unceasing customer service

Track the below URL for one-step submission https://juniperpublishers.com/online-submission.php 